\title{
KOMPROMI SEBAGAI KUNCI BUDAYA DEMOKRASI
}

\author{
Irena Novarlia \\ Universitas Pendidikan Indonesia \\ Email: Irenanovarlia_f@yahoo.com
}

Naskah diterima: 8 September 2015, direvisi: 13 Oktober 2015, disetujui: 2 Desember 2015

\begin{abstract}
This article aims to examine the compromise as a key democratic culture. When, tolerance and freedom excluded from the mechanism of the social system, not only makes the further democratic culture of social authority, but social change will be very few are friendly and do not give hope for avoiding conflict. Compromise is the best way and elegant in resolving differences in the interests of democratic culture because it upholds equality, maintaining the balance between rights and obligations, cultivate the attitude of prudence and justice, familiarize consensus in decision making as well as promoting unity and national unity. Compromise as a key democratic culture is an expression of political intelligence without the interests of the group to achieve stability.

Keywords: compromise; a democratic culture

Artikel ini bertujuan menelaah kompromi sebagai kunci budaya demokrasi. Ketika, toleransi dan kebebasan tersisih dari mekanisme sistem sosial, bukan hanya membuat budaya demokrasi semakin jauh dari otoritas sosial, namun perubahan sosial akan sedikit sekali bersifat ramah dan tidak memberi harapan untuk terhindarnya konflik. Kompromi merupakan cara terbaik dan elegan dalam menyelesaikan berbagai perbedaan kepentingan dalam budaya demokrasi karena menjunjung tinggi persamaan, menjaga keseimbangan antara hak dan kewajiban, membudayakan sikap bijak dan adil, membiasakan musyawarah mufakat dalam mengambil keputusan serta mengutamakan persatuan dan kesatuan bangsa. Kompromi sebagai kunci budaya demokrasi merupakan ekspresi kecerdasan politik tanpa mengutamakan kepentingan kelompok untuk mewujudkan stabilitas.
\end{abstract}

Kata kunci: kompromi; otoritas sosial; budaya demokrasi

Pengutipan: Novarlia, I. (2015). Kompromi sebagai Kunci Budaya Demokrasi. SOSIO DIDAKTIKA: Social Science Education Journal, 2(2), 2015, 194-202. doi:10.15408/sd.v2i2.2820.

Permalink/DOI: http://dx.doi.org/10.15408/sd.v2i2.2820 


\section{A. Pendahuluan}

Budaya demokrasi saat ini, semakin mengalami perkembangan tidak hanya menjadi wacana intelektual melainkan impian politik berbagai negara di dunia khususnya negaranegara berkembang. Indonesia sebagai salah satu negara berkembang telah melewati tahapan sejarah yang sangat penting diantaranya dengan pelaksanaan pemilihan presiden secara langsung. Namun, ini baru langkah awal. Sangatlah dini mengklaim Indonesia sebagai negara demokrasi yang sukses. Karena, untuk mencapai tujuan tersebut diperlukan proses yang dapat mengubah pola pikir, karakter, dan hukum masyarakatnya untuk lebih memahami makna budaya demokrasi.

Budaya demokrasi menempatkan rakyat pada posisi yang sangat strategis dalam sistem ketatanegaraan, dapat dikatakan bahwa kekuasaan tertinggi langsung berada di tangan rakyat. ${ }^{1}$ Namun, dalam praktisnya terdapat indikasi cukup kuat yang menganggap budaya demokrasi adalah kelompok mayoritas. Dalam hal ini, apa yang menjadi kehendak mayoritas adalah kebenaran. Kemayoritasan merupakan pemahaman yang menomorsatukan suara terbanyak, tetapi akan cenderung mengabaikan kebebasan sipil sebagai kaum minoritas. Karena itu, budaya demokrasi tidak akan berjalan dengan efektif tanpa adanya kompromi yang sehat antara kelompok mayoritas dan minoritas di dalam masyarakat.

Kompromi merupakan ekspresi dari kecerdasan politik yang dianggap mampu mengamankan kepentingan masyarakat secara lebih baik dan berkesinambungan daripada menampilkan kekuasaan kelompok mayoritas atau minoritas, hal ini ditunjukan dengan terdapatnya kesadaran masyarakat terhadap nilai-nilai praktis budaya demokrasi. Sejalan dengan hal tersebut, kompromi harus terus menerus dilakukan agar terjadi sebuah kesepakatan bersama dan menjadi pegangan bagi masyarakat dalam mewujudkan budaya demokrasi. Berdasarkan uraian tersebut, tulisan ini dimaksudkan untuk menjelaskan tentang kompromi sebagai kunci budaya demokrasi

\footnotetext{
1 Moh. Koesnardi dan Bintan R. Saragih, Ilmu Negara (Jakarta: Gaya
} Media Pratama, 1998), Cet. 2, h. 167-191. yang mengarah pada suatu pendekatan ke arah cita-cita penentuan kehendak bersama secara sempurna.

\section{B. Konsep Kompromi}

Konsep kompromi mengandung arti, berkonsesi (memberikan sesuatu untuk diberikan kepada pihak lawan untuk menukarkan sesuatu yang kita inginkan), dengan sejumlah tuntutan tertentu, dilepaskannya sebagian tuntutan-tuntutan sendiri untuk mencapai kata sepakat dengan partai lain. ${ }^{2}$ Dengan demikian, kompromi dilakukan sebagai upaya untuk memperoleh kesepakatan di antara dua pihak yang saling berbeda pendapat atau berselisih paham. Hal penting yang harus dikembangkan dalam kompromi adalah terjadinya pertukaran manfaat dengan cara yang diterima oleh semua pihak dan hasil yang diperoleh secara bersamasama ini untuk memperoleh legitimasi sehingga akan tercipta stabilitas.

Setiap manusia memiliki sifat ego yang tampil pada diri seseorang dalam bentuk persepsi tentang diri sendiri. Di antara persepsi yang muncul, merasa lebih baik, lebih pintar, lebih benar dari orang lain yang pada suatu gilirannya, dia akan menganggap orang lain lebih bodoh, lebih salah dan lebih buruk dibanding dirinya. Apabila, perasaan ini dibiarkan lepas begitu saja tanpa ada kontrol diri yang sehat, tepat dan bijaksana, maka dia akan menolak segala bentuk kritik karena dia merasa selalu benar dan akan marah ketika ada yang menyalahkannya karena merasa orang lain yang salah. Kompromi merupakan pernyataan sikap yang menjadi jalan tengah antara pihak yang kalah dan menang dalam suatu perbedaan. Semua orang ingin menang dan tidak ada yang mau mengalah tetapi, untuk menjadi seorang pemenang tentu harus ada yang kalah. Lalu, siapa yang mau kalah kalau masing-masing pihak ingin menang? Solusinya: masing-masing pihak harus mau kalah untuk mencapai kemenangan. Itulah kompromi.

Kompromi merupakan prinsip dan salah satu urat saraf yang memungkinkan

\footnotetext{
2 Lenin, “Kumpulan Karya”, Edisi Rusia Keempat, jilid 25, h. 282-287
} dalam https://www.marxists.org, diakses 7 September 2015. 
berjalannya politik. Kompromi adalah cara terbaik dan paling elegan dalam menyelesaikan berbagai perbedaan dalam kepentingan politik. ${ }^{3}$ Kompromi harus di arahkan kepada kepentingan yang lebih besar, kompromi yang tidak diarahkan pada pembagian kekuasaan melainkan diarahkan pada kepentingan rakyat banyak dan kepentingan bangsa.

Sikap kompromistis dapat dilakukan dengan mengubah pola pikir, dengan membalik persepsi dasar manusia atas dirinya sendiri dan orang lain. Menyadari bahwa, kaidah menganggap bahwa diri sendiri mungkin saja benar tapi orang lain belum tentu salah; juga dengan mengontrol keinginan diri untuk menyalahkan orang lain dan lebih menekankan pada introspeksi diri. Sadar bahwa, masalah dapat timbul sebagai akibat sikap diri baik langsung atau tidak. Kompromi memiliki makna penyelesaian perbedaan dengan konsesi bersama antara dua pihak dengan saling menyesuaikan diri dan mengalah. Dengan demikian, kesepakatan dapat tercapai dengan cara saling mengalah.

Kompromi dalam tataran praktis memiliki fungsi untuk mengatasi konflik ketika penerapan kepentingan dari pihak yang lebih kuat tidak memberikan solusi. Melalui kompromi dua pihak atau lebih sepakat untuk menghilangkan hak mereka dalam memaksakan seluruh kepentingan mereka sendiri, sehingga seluruh pihak dapat menyadari sasaran politik mereka sebanyak mungkin. Cara ini melibatkan proses kompromi yang membuat semua pihak menyadari bahwa pencapaian nilai dan kepentingan kelompok secara penuh tidak mungkin dilakukan dan atau bukanlah suatu langkah yang cerdas. Hal tersebut, didasari atas suatu pandangan bahwa segala bentuk kesepakatan yang wajar terhadap permintaan satu pihak dapat dilakukan untuk dapat mencapai bagian-bagian lain yang lebih penting. Dengan demikian, kompromi mencerminkan pemikiran bahwa sasaran dan kepentingan suatu pihak akan sulit untuk direalisasikan sepenuhnya, namun harus selalu dinegosiasikan dengan kepentingan, nilai dan sasaran pihak-pihak lain karena mereka juga memiliki pembenaran-

\footnotetext{
3 A. Muhaimin Iskandar, Gus Dur Yang Saya Kenal: Sebuab Catatan Tentang Transisi Demokrasi Kita (Jakarta: PT LKIS Pelangi Aksara, 2004), h. 111.
}

pembenaran atas kepentingan mereka.

Kompromi sebagai situasi saling memberi dan menerima sambil menyatukan kepentingan masyarakat, merupakan proses timbal balik keuntungan dan kerugian yang adil, dimana tidak ada pihak yang berusaha mencapai sasaran mereka sendiri dengan segala upaya tanpa mempertimbangkan kepentingan dan sasaran pihak-pihak lain, disini tidak ada pihak yang kalah. ${ }^{4}$ Dengan demikian dapat menciptakan rasa percaya karena satu sama lain saling bergantung dan bersikap adil serta adanya nilai baik, saling mempertimbangkan.

Kompromi yang sukses dengan demikian akan mungkin diraih oleh semua pihak yang terlibat ataupun tidak terlibat langsung dapat merasakan pertimbangan, kerjasama yang adil, mempertimbangkan banyak kepentingan di dalam proses pengambilan keputusan bersama, menghargai alasan yang baik untuk keseluruhan hasil politik yang jauh lebih bermakna daripada sekedar penggunaan kekuatan belaka.

\section{Konsep Demokrasi}

Demokrasi bukanlah konsep yang mudah dipahami, karena memiliki banyak konotasi makna, variatif, evolutif dan dinamis. ${ }^{5}$ Demokrasi bermakna variatif karena sangat bersifat interpretatif. Demokrasi juga merupakan konsep evolutif dan dinamis karena selalu mengalami perubahan, baik bentuknya maupun substansinya sesuai dengan konteks dan dinamika sosio historis dimana konsep demokrasi lahir dan berkembang.

Budaya demokrasi terdiri atas dua kata, yaitu budaya dan demokrasi. Budaya berarti hasil kemampuan akal manusia dalam lingkungan kehidupannya. Sedangkan menurut asal kata, demokrasi memiliki arti "rakyat berkuasa" (kata Yunani demos berarti rakyat, kratos/ kratein berarti kekuasaan/berkuasa). ${ }^{6}$ Konsep tersebut selalu menempatkan rakyat pada posisi yang sangat strategis dalam sistem ketatanegaraan, walaupun pada tataran implementasinya terjadi perbedaan

\footnotetext{
4 Thomas Meyer, Compromise (Jakarta: Friedrich-Ebert-Stiftung (FES), 2008), h. 11.

5 Muhammad Zulfan Hakim, Demokrasi dalam Pilkada di Indonesia, dalam http://repository.unhas.ac.id, diakses pada 7 September 2015, h. 1.

6 Miriam Budiardjo, Dasar-Dasar Ilmu Politik. (Jakarta: Gramedia, 2008).
} 
antara negara yang satu dengan negara yang lain. Karena, berbagai varian implementasi demokrasi tersebut, maka di dalam literatur kenegaraan dikenal beberapa istilah demokrasi yaitu demokrasi konstitusional, demokrasi parlementer, demokrasi terpimpin, demokrasi pancasila, demokrasi rakyat, demokrasi soviet, demokrasi nasional, dan lain sebagainya.

Menurut Affan, makna budaya demokrasi terdiri dalam dua bentuk, yaitu pemaknaan secara normatif dan empirik. ${ }^{7}$ Demokrasi normatif adalah demokrasi yang secara ideal hendak dilakukan oleh sebuah negara. Sedangkan demokrasi empirik adalah demokrasi yang perwujudannya telah ada pada dunia politik

praktis. Demokrasi empirik dianggap diterima oleh masyarakat karena dirasakan sesuai dengan norma-norma yang ada dalam masyarakat selama ini. ${ }^{8}$

Budaya demokrasi mempunyai pengertian kemampuan manusia yang berupa sikap dan kegiatan yang mencerminkan nilai-nilai demokrasi seperti menghargai persamaan, kebebasan, dan peraturan. Budaya demokrasi juga dapat dikatakan sebagai bentuk aplikasi atau penerapan nilai-nilai yang terkandung dalam prinsip demokrasi itu sendiri. Terdapat beberapa ahli yang menyatakan prinsip-prinsip budaya demokrasi antara lain.

Miriam Budiardjo berpendapat bahwa prinsip-prinsip budaya demokrasi sebagai berikut. ${ }^{?}$

1. Perlindungan konstitusional, dalam arti bahwa konstitusi selain menjamin hak-hak individu, harus menentukan pula prosedur untuk memperoleh perlindungan atas hakhak yang dijamin.

2. Badan kehakiman yang bebas dan tidak memihak.

3. Pemilihan umum yang bebas.

4. Kebebasan umum untuk menyatakan pendapat.

5. Kebebasan untuk berserikat/berorganisasi dan beroposisi.

\footnotetext{
7 Afan Gaffar, Politik. Indonesia: Transisi Menuju Demokrasi, (Yogyakarta: Pustaka Pelajar, 2005), h. 15.$$
8 \text { Ibid. }
$$$$
9 \text { Op. cit., Miriam Budiardjo, h. 118-119. }
$$

6. Pendidikan kewarganegaraan.

Henry B. Mayo sebagaimana dikutip dalam Miriam Budiardjo mengungkapkan prinsip dari demokrasi yang akan mewujudkan suatu sistem politik yang demokratis antara lain. ${ }^{10}$

1. Menyelesaikan perselisihan dengan damai dan secara melembaga.

2. Menjamin terselenggaranya perubahan secara damai dalam suatu masyarakat yang sedang berubah.

3. Menyelenggarakan pergantian pimpinan secara teratur.

4. Membatasi pemakaian kekerasan sampai minimum.

5. Mengakui serta menganggap wajar adanya keanekaragaman.

6. Menjamin tegaknya keadilan.

Kemudian, menurut Alamudi sebagaimana dikutip oleh Sri Wuryan dan Syaifullah, suatu negara dapat disebut berbudaya demokrasi apabila memiliki soko guru demokrasi sebagai berikut. $^{11}$

1. Kedaulatan rakyat.

2. Pemerintahan berdasarkan persetujuan dari yang diperintah.

3. Kekuasaan mayoritas.

4. Hak-hak minoritas.

5. Jaminan hak-hak asasi manusia.

6. Pemilihan yang bebas dan jujur.

7. Persamaan di depan hukum.

8. Proses hukum yang wajar.

9. Pembatasan pemerintahan secara konstitusional.

10. Pluralisme sosial, ekonomi, dan politik.

11. Nilai-nilai toleransi, pragmatisme, kerja sama dan mufakat

Prinsip-prinsip demokrasi yang diuraikan tersebut, sesungguhnya merupakan nilainilai yang diperlukan untuk mengembangkan suatu bentuk pemerintahan yang demokratis.

10 Ibid., Op. cit., Miriam Budiardjo.

11 Syaifullah dan Sri Wuryan, Imu Kewarganegaraan (Civics) (Bandung: Laboratorium Kewarganegaraan, 2006). h. 84 
Berdasarkan prinsip-prinsip inilah, sebuah pemerintahan yang demokratis dapat ditegakkan. Sebaliknya tanpa prinsip-prinsip tersebut, bentuk pemerintah yang demokratis akan sulit ditegakkan. Secara komprehensif kriteria demokrasi juga diajukan oleh Gwendolen M. Carter, John H. Herz dan Henry B. Mayo. Carter dan Herz mengkonseptualisasikan demokrasi sebagai pemerintahan yang dicirikan oleh dan dijalankannya melalui prinsip-prinsip ${ }^{12}$ :

1. Pembatasan terhadap tindakan pemerintah untuk memberikan perlindungan bagi individu dan kelompok dengan jalan menyusun pergantian pimpinan secara berkala, tertib dan damai, dan melalui alatalat perwakilan rakyat yang efektif;

2. Adanya sikap toleransi terhadap pendapat yang berlawanan;

3. Persamaan di depan hukum yang diwujudkan dengan sikap tunduk kepada rule of law tanpa membedakan kedudukan politik;

4. Adanya pemilihan yang bebas dengan disertai adanya model perwakilan yang efektif;

5. Diberinya kebebasan partisipasi dan beroposisi bagi partai politik, organisasi kemasyarakatan, masyarakat dan perseorangan serta prasarana pendapat umum semacam pers dan media massa;

6. Adanya penghormatan terhadap hak rakyat untuk menyatakan pandangannya betapa pun tampak salah dan tidak populernya pandangan itu; dan

7. Dikembangkannya sikap menghargai hakhak minoritas dan perorangan dengan lebih mengutamakan penggunaan caracara persuasif dan diskusi daripada koersif dan represif.

Dalam rangka mengimplementasikan semua kriteria, prinsip, nilai, dan elemen-elemen demokrasi tersebut di atas, perlu disediakan beberapa lembaga sebagai berikut ${ }^{13}$ :

1. Pemerintahan yang bertanggung jawab;
2. Suatu Dewan Perwakilan Rakyat yang mewakili golongan-golongan dan kepentingan-kepentingan dalam masyarakat yang dipilih dengan pemilihan umum yang bebas dan rahasia dan atas dasar sekurang-kurangnya dua calon untuk setiap kursi. Dewan/perwakilan ini mengadakan pengawasan (kontrol) memungkinkan oposisi yang konstruktif dan memungkinkan penilaian terhadap kebijakan pemerintah secara kontinyu;

3. Suatu organisasi politik yang mencakup satu atau lebih partai politik. Partai partai menyelenggarakan hubungan yang kontinyu antara masyarakat umum dan pemimpin-pemimpinnya

4. Pers dan media massa yang bebas untuk menyatakan pendapat; dan

5. Sistem peradilan yang bebas untuk menjamin hak-hak asasi dan mempertahankan keadilan.

Dengan demikian, kekuasaan diperoleh melalui mekanisme budaya demokrasi, karena konsepsi demokrasi menempatkan manusia sebagaipemilikkedaulatanyangkemudiandikenal dengan prinsip kedaulatan rakyat sehingga dapat dipastikan akan menjadi kekuasaan yang demokratis karena kehendak rakyatlah sebagai landasan legitimasinya. Namun, kekuasaan berdasarkan legitimasi-legitimasi tersebut, dengan sendirinya, mengingkari kesamaan dan kesederajatan manusia, karena mengklaim kedudukan kelompok lebih tinggi dari kelompok lainnya. Selain itu, kekuasaan yang berdasarkan legitimasi tersebut akan menjadi kekuasaan yang absolut, karena asumsi dasarnya menempatkan kelompok yang memerintah sebagai pihak yang berwenang secara istimewa dan lebih tahu dalam menjalankan urusan kekuasaan negara. Karena, demokrasi merupakan cara yang paling aman untuk mempertahankan kontrol atas suatu negara hukum. ${ }^{14}$ 


\section{Kompromi sebagai Kunci Budaya Demokrasi}

Kompromi adalah suatu hal normal yang dapat dilakukan dalam kehidupan keluarga, bermasyarakat, ataupun bernegara sebagai cara untuk menemukan solusi. Kompromi dianggap sebagai kunci budaya demokrasi jika mampu melahirkan pengalaman, dimana lembaga-lembaga demokrasi yang berpartisipasi mematuhi kesepakatannya meskipun dalam beberapa hal bertentangan dengan kepentingan mereka sendiri.

Budaya demokrasi yang pada hakikatnya adalah kedaulatan dari rakyat, oleh rakyat dan untuk rakyat, telah bergeser menjadi dari rakyat, oleh penguasa, dan untuk pengusaha. Rakyat kini justru kehilangan hak-hak dasarnya sebagai pemegang kedaulatan tertinggi. Akibatnya, timbul kecenderungan konflik dan krisis yang mengarah ke perselisihan serta ketidakpercayaan rakyat pun semakin besar. Kondisi tersebut, menuntut adanya jaminan kerja dan kinerja lembaga-lembaga demokrasi secara layak dan berkesinambungan diantaranya melalui kompromi yang cerdas.

Kompromi yang cerdas telah terbukti menjadi salah satu syarat suskesnya sebuah demokrasi. Sehingga, ketika kondisi tersebut terjadi, masyarakat dapat memahami bahwa kepentingan seluruh individu di dalam budaya demokrasi harus dipertimbangkan secara adil. Semua warga negara akan memiliki dasar yang solid dengan kesadaran akan pentingnya mengembangkan kompromi. Karena, demokrasi bukanlah sebuah mesin yang komponen utamanya terdiri dari lembagalembaga. ${ }^{15}$ Kompromi dapat diterima, dipercaya dan realistis dalam mengejar sasarannya hanya apabila ada alasan yang baik yang sejalan dengan sasaran dan janji-janji awal dari masyarakat.

Kompromi melatih keterampilan yang diperlukan dalam budaya demokrasi. Kemampuan untuk menerima sebanyak mungkin kepentingan yang sah yang terwakili di masyarakat lalu mengintegrasikannya ke dalam proses pembuatan dan pengambilan keputusan politik merupakan suatu prinsip penting dalam budaya demokrasi. Untuk alasan-alasan ini, kerjasama atau kolaborasi dan realisasi kompromi yang cerdas akan mengembangkan sikap, kebiasaan dan keterampilan yang dibutuhkan demokrasi agar dapat berfungsi dan mendapatkan pengakuan dari seluruh warga negara.

Proses pengambilan keputusan yang otoriter jelas-jelas bertentangan dengan prinsipprinsip demokrasi. Hal ini tidak hanya tidak dapat diterima atas dasar alasan-alasan normatif, tetapi ini juga menjadi strategi aksi politik yang dapat mengakibatkan destabilisasi karena kepemimpinan otoriter selalu melahirkan resistensi dan disintegrasi atas sistem yang ada. Strategi-strategi untuk mencapai konsensus selalu menjadi hal yang menarik, namun sering kali hanya praktis dilakukan dalam batasanbatasan tertentu dan apabila terkait dengan pertanyaan-pertanyaan mendasar yang ada di masyarakat, termasuk harus mempertimbangkan jumlah waktu yang diperlukan dan kesulitan dalam mengatur proses diskusi untuk seluruh bagian masyarakat.

Keputusan-keputusan mayoritas tanpa kompromi, dan tidak mengakomodir kepentingan minoritas, tidak menjadi suatu proses politik yang cerdas terutama karena dua alasan berikut: di satu sisi, strategi mayoritas yang dominan mengucilkan kelompok-kelompok penting di masyarakat dari demokrasi, terutama, ketika hal itu melibatkan nilai-nilai dan tujuan yang penting. Dengan demikian, hal tersebut merendahkan fondasi politik dan budaya dari demokrasi itu sendiri, meskipun dari luar tampak seperti suatu pendekatan yang formal. Hal tersebut bertentangan dengan persepsi sebagian besar masyarakat bahwa pada akhirnya proses pengambilan keputusan yang demokratis bertujuan melayani kepentingan semua orang. Alasan kedua adalah: keputusan-keputusan yang diambil tanpa kompromi sering kali tidak stabil karena pihak yang tidak diikutsertakan dalam pertimbangan, sering kali secara aktif mendorong terjadinya perubahan. Dengan demikian, sebagian besar keputusan-keputusan ini tidak diambil untuk kepentingan jangka panjang dari pihak yang berkuasa. ${ }^{16}$ 
Budaya demokrasi mengakui adanya sifat kodrat manusia sebagai makhluk individu dan makhluk sosial dalam kehidupan masyarakat, berbangsa, dan bernegara. Karena itu, prinsipprinsip kompromi yang perlu dikembangkan sebagai kunci budaya demokrasi antara lain.

1. Menjunjung tinggi persamaan

Kompromi sebagai kunci budaya demokrasi mengandung makna bahwa setiap orang harus mau berbagi dan terbuka menerima perbedaan pendapat, kritik dan saran dari orang lain. Dengan demikian, melalui kompromi mengajarkan bahwa setiap manusia memiliki persamaan harkat dan derajat dari sumber yang sama sebagai makhluk ciptaan Yang Maha Esa. Karena itu, dalam kehidupan sehari-hari hendaknya setiap orang mampu membuat dan bertindak untuk menghargai orang lain sebagai wujud kesadaran diri untuk menerima keberagaman dalam masyarakat.

2. Menjaga keseimbangan antara hak dan kewajiban

Kompromi sebagai kunci budaya demokrasi diperlukan. Karena, dalam kehidupan bermasyarakat, terdapat batas-batas yang harus di hormati bersama berupa hak-hak yang dimiliki orang lain sehingga batasan norma yang berlaku dan di patuhi. Penerapan hak-hak tersebut bukanlah sesutu yang mutlak tanpa batas, untuk itu, dalam upaya mewujudkan tatanan kehidupan sehari-hari yang bertanggung jawab terhadap Tuhan, diri sendiri, dan orang lain perlu dengan sebaik-baiknya. Dengan demikian, melalui kompromi, setiap manusia menerima fitrah hak asasi dari Tuhan Yang Maha Esa berupa hak hidup, hak kebebasan, dan hak memiliki sesuatu.

3. Membudayakan sikap yang adil dan bijak

Kompromi sebagai kunci budaya demokrasi terjadi apabila masyarakat mampu mengembangkan budaya bijak dan adil dalam rangka mewujudkan kehidupan yang saling menghormati harkat dan martabat orang lain, tidak diskriminatif, terbuka, dan menjaga persatuan dan kesatuan lingkungan masyarakat sekitar. Bijak dan adil dalam makna yang sederhana adalah perbutan yang benar-benar dilakukan dengan perhitungan, mawas diri, mau memahami yang dilakukan orang lain dan proporsional. Sikap adil dalam kompromi bermakna bahwa semua pihak harus rela mengorbankan separuh kemauannya dan membiarkan masing-masing pasangannya "memenangkan" pertandingan. Sama-sama menang artinya keduanya sama-sama mengalami separuh kekalahan. Jangan mencari menang sendiri tetapi juga jangan mau untuk selalu jadi pecundang yang selalu berada di pihak yang kalah.

\section{Musyawarah dan mufakat}

Kompromi sebagai kunci budaya demokrasi terjadi apabila dalam mengambil keputusan dilakukan melalui musyawarah mufakat sebagai salah satu nilai dasar budaya bangsa Indonesia yang sejak lama telah diperaktikkan masyarakat dalam kehidupan sehari-hari. Dalam musyawarah mufakat terkandung makna bahwa pada setiap kesempatan yang berhubungan dengan pengambilan keputusan diperlukan kesadaran dan kearifan untuk memutuskan, sebelum suatu keputusan di terapkan selalu di dahului dengan kompromi dan mau mendengar dari berbagai pihak, juga selalu di upayakan untuk memahami terlebih dahulu persoalan-persoalan yang ada. Kompromi dengan musyawarah mufakat akan menghasilkan keputusan yang mampu memuaskan banyak pihak sehingga dapat terhindar dari konflik-konflik vertikal maupun horizontal.

\section{Mengutamakan persatuan dan kesatuan nasional}

Kompromi sebagai kunci budaya demokrasi terjadi apabila dalam kehidupan bermasyarakat, berbangsa, dan bernegara, lebih mengutamakan kepentingan orang lain/umum dari kepentingan pribadi. Kesadaran setiap warga negara untuk mengutamakan persatuan dan kesatuan merupakan wujud cinta dan bangsa terhadap bangsa dan negara. Makna penting dalam memahami sikap mengutamakan persatuan dan kesatuan adalah bagaimana setiap orang mampu berbuat tanpa pamrih untuk kepentingan bangsa dan negara.

Budaya demokrasi memiliki kecenderungan untuk hidup bermasyarakat tidak semata-mata 
untuk memenuhi kebutuhan pokok, akan tetapi juga menghasilkan kelengkapan hidup yang akan memberikan kepada manusia kebahagiaan, tidak saja material namun juga spiritual. Salah satu kelengkapan hidup adalah timbulnya bermacam ide/kehendak. ${ }^{17}$ Di dalam masyarakat, sudah barang tentu akan membentuk pemilahanpemilahan ide atau kehendak. Berbagai pendapat mengenai sebuah persoalan akan muncul secara acak. Dari titik inilah muncul pola kepentingan yang berujung pada adanya suara mayoritas dan minoritas, yang masingmasing mempunyai hak dan kewajiban. Dalam pandangan Hans Kelsen, suara mayoritas tidak melahirkan dominasi absolut atau dengan kata lain, dalam bahasa Hans Kelsen, adalah kediktatoran mayoritas atas minoritas. Prinsip mayoritas dalam masyarakat demokrasi, hanya dapat dijalankan jika segenap warga masyarakat dalam sebuah negara diperbolehkan turut serta dalam pembentukan tatanan hukum. Inilah yang kemudian melahirkan istilah kompromi. ${ }^{18}$

Kompromi merupakan proses pembuatan keputusan yang dapat memungkinkan terjadinya stabilitas jangka panjang dan keamanan budaya demokrasi secara bersamaan. Kompromi adalah kunci dari budaya demokrasi. Kompromi dapat diterima, dipercaya dan realistis dalam mengejar sasarannya hanya apabila ada alasan yang baik yang sejalan dengan sasaran dan janji-janji awal dari peserta yang melaksanakannya.

\section{E. Penutup}

Kompromi merupakan bagian penting dalam budaya demokrasi. Karena, merupakan ekspresi kecerdasan politik tanpa mengutamakan kepentingan kelompok mayoritas maupun minoritas dengan memupuk kesadaran dan kepercayaan masyarakat untuk mewujudkan stabilitas. Prinsip-prinsip kompromi yang perlu dikembangkan sebagai kunci budaya demokrasi antara lain; menjunjung tinggi persamaan, menjaga keseimbangan antara hak dan kewajiban membudayakan sikap bijak dan adil, membiasakan musyawarah mufakat dalam mengambil keputusan serta mengutamakan

\footnotetext{
17 Hans Kelsen, Teori Umum Tentang Hukum dan Negara (Bandung: Nuansa dan Nusamedia, 2006).

18 Munawir Sadjali, Islam dan Tata Negara; Ajaran, Sejarah, dan Pemikiran (Jakarta: UI Press, 1993), h. 51.
}

persatuan dan kesatuan nasional. Seorang pemimpin yang melakukan kompromi dan bersedia untuk mengalah bukan berarti pemimpin tersebut lemah. Apabila, pemimpin tersebut tetap memegang teguh tujuan dan tidak menganggu kerangka kehidupan bernegara yang diatur dalam konstitusi serta tidak menabrak prinsip-prinsip moral yang tidak boleh dikorbankan.

Kompromi memainkan peran untuk menjembatani perbedaan diantara dua atau lebih individu/pihak. Ketika, toleransi dan kebebasan mejadi tersisih dari mekanisme sistem sosial, bukan hanya membuat budaya demokrasi akan semakin jauh dari otoritas sosial, namun bentuk-bentuk perubahan sosial akan sedikit sekali bersifat ramah dan tidak memberi harapan bagi terhindarnya kekacauan publik. Hampir dalam setiap hal dibutuhkan sifat kompromis, yakni sifat alamiah manusia sebagai makhluk sosial yang hidup saling berdampingan satu sama lain. Kompromi memainkan peran dalam penyelesaian berbagai sengketa dan konflik. Namun kompromi dalam hal ini berbeda bentuknya dengan kompromi dalam dunia pertemanan. Kompromi sebagai kunci dalam budaya demokrasi, berkaitan erat dengan hukum dan segala perjanjian yang mengikat. Segala bentuk pelanggaran terhadap hukum dan perjanjian tersebut, akan mengakibatkan timbulnya sanksi.

\section{F. Daftar Pustaka:}

Gaffar, Afan. (2005). Politik Indonesia: Transisi Menuju Demokrasi. Yogyakarta: Pustaka Pelajar.

Budiardjo, Miriam. (2008). Dasar-Dasar Ilmu Politik. Jakarta: Gramedia.

Hakim, Z. Muhammad. (2015) Demokrasi dalam Pilkada di Indonesia [Online]. Tersedia: http://repository.unhas.ac.id. [7 September 2015].

Iskandar, A. Muhaimin. (2004). Gus Dur yang saya kenal: sebuah catatan tentang transisi demokrasi kita. Jakarta: PT LKIS Pelangi Aksara. 
Kelsen, Hans. (2006). Teori Umum Tentang Hukum dan Negara. Bandung: Nuansa dan Nusamedia.

Koesnardi, M \& Saragih, R. Bintan. (1998). Imu Negara. Jakarta: Gaya Median Pratama.

Lenin. (2015). Kumpulan Karya. Edisi Rusia Keempat [Online]. Tersedia: https:// www.marxists.org. [7 September 2015].

Meyer, Thomas. (2015). Kompromi Jalur Ideal Menuju Demokrasi [Online]. Tersedia: http:/ / repository.unhas.ac.id.[7 September 2015].
Sadjali, Munawir. (1993). Islam dan Tata Negara; Ajaran, Sejarah, dan Pemikiran. Jakarta: UI Press.

Suseno, F. Magnis. (1997). Mencari Sosok Demokrasi: Sebuah Telaah Filosofis. Jakarta: Gramedia.

Syaifullah dan Wuryan, Sri. (2006). Ilmu Kewarganegaraan (Civics). Bandung: Laboratorium Kewarganegaraan. 